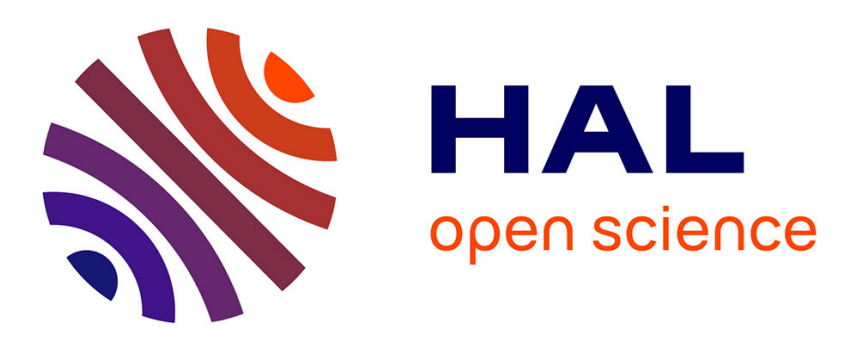

\title{
Of Female Husbands and Boarding School Girls: Gender Bending in Unoma Azuah's Fiction
}

\author{
Chantal Zabus
}

\section{To cite this version:}

Chantal Zabus. Of Female Husbands and Boarding School Girls: Gender Bending in Unoma Azuah's Fiction. Research in African Literatures, 2014, Nigeria's Third-Generation Novel: Preliminary Theoretical Engagements, 9 (2), pp.93-107. hal-01988716

\section{HAL Id: hal-01988716 https://sorbonne-paris-nord.hal.science/hal-01988716}

Submitted on 21 Jan 2019

HAL is a multi-disciplinary open access archive for the deposit and dissemination of scientific research documents, whether they are published or not. The documents may come from teaching and research institutions in France or abroad, or from public or private research centers.
L'archive ouverte pluridisciplinaire HAL, est destinée au dépôt et à la diffusion de documents scientifiques de niveau recherche, publiés ou non, émanant des établissements d'enseignement et de recherche français ou étrangers, des laboratoires publics ou privés.

$$
\text { Copyright }
$$




\section{Uا $\perp$ INDIANA UNIVERSITY PRESS \\ OFFICE OF SCHOLARLY PUBLISHING}

Of Female Husbands and Boarding School Girls: Gender Bending in Unoma Azuah's Fiction Author(s): Chantal Zabus

Source: Research in African Literatures, Vol. 39, No. 2, Nigeria's Third-Generation Novel:

Preliminary Theoretical Engagements (Summer, 2008), pp. 93-107

Published by: Indiana University Press

Stable URL: http://www.jstor.org/stable/20109581

Accessed: 02/03/2014 17:14

Your use of the JSTOR archive indicates your acceptance of the Terms \& Conditions of Use, available at http://www.jstor.org/page/info/about/policies/terms.jsp

JSTOR is a not-for-profit service that helps scholars, researchers, and students discover, use, and build upon a wide range of content in a trusted digital archive. We use information technology and tools to increase productivity and facilitate new forms of scholarship. For more information about JSTOR, please contact support@jstor.org.

Indiana University Press is collaborating with JSTOR to digitize, preserve and extend access to Research in African Literatures. 


\title{
Of Female Husbands and Boarding School Girls: Gender Bending in Unoma Azuah's Fiction
}

\author{
CHANTAL ZABUS \\ Universités Paris XIII, Paris III
}

\begin{abstract}
While Azuah's novel Sky-High Flames (2005) is firmly grounded in the Igbo sociological context, comprising ancestor worship, the cult of a female goddess, polygamy, and the levirate, the novel taps into the practice of female husbandry documented by cultural anthropologists (e.g., Sylvia Leith-Ross and Ifi Amadiume, whose theories I reassess), previous West African literary attempts at representing lesbian seduction, as well relational nexuses within the boarding school system. Nigerian feminisms, I argue, need to make room for the material factors of "doing lesbian." While pointing to this debut novel's reluctance to allow same-sex desire to develop, I also comment on womanly relationality, such as Azuah's displaced (auto)biographical vestment in her aunt's story, as well as on moments of intimacy between women, which augur the new Nigerian novel's capacity to comment on the economy of pleasures and on the way of constituting oneself as the moral subject of one's sexual conduct.
\end{abstract}

I is my contention here that Unoma Azuah's fiction was not created out of a vacuum but taps, possibly unwittingly, into the Igbo ancestral matriarchal past, the practice of female husbandry documented by cultural anthropologists (both British and Nigerian), previous West African literary attempts at representing lesbian seduction, ${ }^{1}$ as well as her own and her relatives' participation in gender bending.

What we know about gender subversion among Igbo women (in Eastern Nigeria) has been mediated via cultural anthropology. The earliest study is without a doubt the British anthropologist Sylvia Leith-Ross's African Women, a Study of the Ibo of Nigeria (1939). With reference to reincarnation in Eziama (between Owerri and $\mathrm{Aba}),{ }^{2}$ Leith-Ross had observed that "a woman might be reincarnated as a man,

RESEARCH IN AFRICAN LITERATURES, Vol. 39, No. 2 (Summer 2008). @ 2008 
but not vice versa" (101). Ifi Amadiume in her Male Daughters, Female Husbands (1987), especially in relation to Nnobi, in Idemili Government Area southeast of Onitsha, took Leith-Ross to task, calling her book "racist" (13). Amadiume recognizes that Leith-Ross "was familiar with Igbo women's feminism and ambition for power," yet she adds: "That the women [Leith-Ross] studied did not wish to become men, but males, was beyond Leith-Ross's imagination" (15). To be fair, it was not beyond Leith-Ross's imagination but that of her Nnaeto female informant who had deemed it "very foolish for a man to wish to become a woman'" and the women present said frankly that "they would like to become men." But, Leith-Ross continues, "I could not get them to explain themselves fully. This is to be regretted as I had occasionally caught glimpses of some peculiar conception of sex or of a thread of bi-sexuality running through everything ... or of a lack of differentiation between the sexes-or of an acceptance of the possibility of the transposition of sex-which it could have been interesting to study" (101). Notwithstanding Amadiume's biased reading and partial quoting of Leith-Ross's text, it remains that her work on Igbo "female husbands" helped popularize the phrase when, to readers steeped in British literature, the phrase- "female husband"-may have conjured up Henry Fielding's 1746 pot-boiling pamphlet of that name about a "lesbian en travesti," based on a real-life cross-dresser who was tried for vagrancy after she (under a male name) married a woman, who was not too long in discovering the subterfuge.

Female husbands in the Igbo context, then and now, are generally widows without a male offspring, who take on "wives" to produce heirs for their husbands' lineages. The "wives" then take in male lovers, have children who are in turn handed over to the "female husbands." Families whose lineages are in danger of dying out due to lack of male heirs encourage their eldest daughter to stay home as the "son" of the family, take in lovers and bear children, hopefully sons to perpetuate the family name.

Amadiume, who, incidentally, features among the writers whom Azuah admires most, as she reported in an interview with Nnorom Azuonye, contends that daughters could indeed become sons and consequently male, after the nhanye practice of ritualistically transforming a daughter into a son or "male daughter." Also, women could become husbands and consequently males in relation to their wives in a woman-to-woman marriage. However, as Amadiume's own book subtitle, Gender and Sex in an African Society, acknowledges, the distinction between biological sex and its social construction, gender, is a relatively recent theoretical concept that Leith-Ross could not have used in its contemporary sense, all the more so since Leith-Ross used "man" (nwoke) and "woman" (nwaanyi) to refer to "male" (oke) and "female" (anyi). In all fairness, Leith-Ross, who is conversant with, Fulani grammar, if not Igbo, and has even written a book on that subject, cannot be faulted for not making this distinction, all the more so since recent Igbo dictionaries do not recognize either the contraction of nwa-oke (male child) into nwoke (man) nor that of of nwa-anyi (female child) into mwanyi (woman), nor even the suffix -anyi, which Amadiume also uses (89). ${ }^{3}$ Leith-Ross's study thus remains the earliest instance of the awareness of female Igbo gender bending before its conceptualization. And, as Joseph M. Carrier and Stephen O. Murray (254), following Denise O'Brien (109), remind us, woman-woman marriage has been documented in more than thirty African populations, including the Nandi, Kikuyu, and Luo 
of Kenya, and the Venda in South Africa. Amadiume's study thus joins a brace of anthropological works on female husbands, going as far back as the early 1950s with Evans-Pritchard's seminal study of the Nuer practice. ${ }^{4}$

Amadiume's most original contribution lies more in her argument that the flexibility of Igbo gender construction is inscribed in the Igbo grammatical construction of gender, which, because of the neuter particle in subject or object pronouns, cancels the very idea of gender distinction between males and females. She concludes that " $t]$ here is, therefore, no language or mental adjustment or confusion in references to a woman performing a typical male role" (17). Since the third-person singular pronoun, $O$, stands for both male and female unlike $h e$ and she and the third-person singular of the possessive pronoun, ya, stands for both his and hers, Amadiume's thesis is that "the Igbo non-distinctive subject pronoun allows a more flexible semantic system, in which it is possible for men and women to share attributes" (89). Although seductive, such an argument makes one wonder if the inherent flexibility of semantics can be stretched to accommodate a society that had thirteen genders. "Oh yes, one says, masculine, feminine and neuter," Margaret Mead ventriloquized in Male and Female (1949), "and what in the world are the other ten?" (12). Taking her cue from R. N. Henderson's The King in Every Man: Evolutionary Trends in Onitsha Ibo Society and Culture, Amadiume concludes that the Igbo word for wife, onye be, is a genderless expression meaning "a person who belongs to the home of the master of the home" (90) and that the "master," or di-bi-uno (i.e., one in a master relationship to a household, which Amadiume misspells di-bu-no), can be a woman. The practice still exists in different Igbo communities in contemporary times but the question that anthropologist Regenia Smith Oboler asked in 1980- "Is the Female Husband a Man?"- is still very much in the open, suspended ... queer.

What is cruelly missing, however, from Amadiume's account of female husbands among the Nnobi is the sexual dimension of such formations, that is, femalefemale sexuality and desire. In relating the aftermath of the Ekwe ceremony, whereby the Ekwe title conveys control of others' services, Amadiume mentions that the co-wives, or inyom di, would be expected to show respect and honor (ugwu) to the titled Ekwe woman "through the ceremony of crawling, one after another, between her legs, while she sat with legs astride" (44). Notwithstanding the obvious connotations of the ritual, as a token of acceptance of the female husband's social superiority and authority, there is an implicit sexuality that is not addressed and that hints at a larger libidinal economy in Igbo woman-to-woman marriage, as is the case in the "mummy-baby" relationships in Lesotho and other parts of the African continent (see Gay and Kendall).

Needless to say, anthropologists have been eager to dispel any thought of lesbianism within woman-woman marriages. Speaking of the Nandi of Kenya, George W. B. Huntingford hastens to say that "[t]here was no lesbianism involved here, for the female husband [manong'otiot] could have her own men friends and the wife could have intercourse with any man of whom her 'husband' approved" (412). ${ }^{5}$ Only Melville Herskovits, it seems, suggested that homosexuality in the form of mutual masturbation might be involved in woman-woman marriages in Dahomey, but his work of the 1930s was disparaged by feminist anthropologists like Eileen Krige and Christine Obbo. ${ }^{6}$ Some elements in the Igbo context of dyadic relations, however, suggest female empowerment through homosexuality and 
the woman-to-woman marriage may indeed have provided a legitimate niche for what would be called in postmodern parlance "a lesbian couple." Also, more largely, it signals variant sexualities in Nigeria, that still need to be explored. As a case in point, in Hausa (Northern Nigerian) society, relationships between the 'yan kifi, or "male lesbians," that is, "passive" homosexuals, or the "yan daudu who have relations between themselves rather than with their "active" 'husbands' (miji), further complicate Nigerian sexual variants because it does not exclude marriage with a woman under Muslim law.

The Nigerian critic Oladele Taiwo has famously proclaimed in his 1984 book that lesbianism, if "tenable in Europe [. . .] has no chance of succeeding in Africa" (24). Speaking of the Ghanaian Ama Ata Aidoo's Our Sister Killjoy (1977), which features a moving encounter between Sissie, a Ghanaian female student doing volunteer work in a pine nursery in Germany, and Marija Sommer, a Bavarian housewife, Taiwo endorsed Sissie's rejection of Marija's sexual overtures:

\footnotetext{
Sissie felt Marija's cold fingers on her breast. The fingers of Marija's hand touched the skin of Sissie's breasts while her other hand groped round and round Sissie's midriff, searching for something to hold on to.

It was the left hand that woke her up to the reality of Marija's embrace. The warmth of her tears on her neck. The hotness of her lips against hers.

As one does from a bad dream, impulsively, Sissie shook herself free. With too much effort, unnecessarily, so that she unintentionally hit Marija on the right cheek with the back of her right hand. (64)
}

Although Taiwo reads this passage in terms of rejection, it turns out, upon closer textual scrutiny, that, despite the fact that Marija's advances are couched in terms of a nightmare that Sissie is eager to shake off, this passage also reeks of voluptuous awkwardness, as shown by Sissie's excessive reactions to Marija's kiss and Sissie's thoughts, immediately after Marija's embrace, drifting to the Ghana of her childhood and her sleeping in the bedchamber, "wrapped up in mother's cloth while it rained" (64). Significantly, Marija's left hand plays the underhand, gauche role of lesbian seduction, while Sissie's right hand dexterously puts an abrupt end to this sweet sinistrality. Even Marija's tears are divided over the surface of her face, as her left eye is tearful while "[t]he right eye was completely dry" (65).

Sissie's recuperation of this scene of thwarted intimacy to serve her (and Aidoo's) ideological stabbing at the European colonization, however abject, of the African continent and at Nazism is disappointing. Indeed, Marija becomes "a young Aryan housewife" (65), suddenly decontextualized and anachronistically made to embody the National Socialist Herrenmenschentheorien. ${ }^{7}$ In her botched epiphany, Sissie sees in Marija's shaky composure and in her tear of "loneliness," "Continental unhappiness," which is at the root of European empire-building" (65-66). Yet this scene of apparent rejection is followed by Sissie remembering a British schoolmistress's homophobic chastisement at the Ghanaian Girls' School, upon finding "two girls in bed together" (66), juxtaposed by her wish "that at least, she was a boy. A man" (67). Sissie's reflections are muddled, as Aidoo tugs her character closer and then abruptly away from the stage of queer desire.

Likewise, the Nigerian Titilola A. Shoneyin, in her short story "Woman in Her Season," has portrayed an interracial lesbian relationship, which is foredoomed to failure. Mrs. Akadiran, who is trapped in a loveless marriage, fantasises about 
being happy with the Swiss woman Zerelda on a farm in Zurich, the way Margaret finds balance and happiness when cultivating her farm in Botswana with her woman friend Zenosi at the end of Bessie Head's A Question of Power (1974). The relationship in Shoneyin's short story, however, remains just that-a fantasy, where she features as a Nubian Princess or Egyptian goddess who "began to live for nights when [her] spine would nest beautifully" between Zerelda's "firm, intimidating breasts" under the "satin covers that dissolved the stinging Swiss snow" (Azuah, "Emerging Lesbian Voice" 134, 136). The treatment of whiteness and cold is remarkably more positive than in Our Sister Killjoy. To Aidoo's Sissie, Europeans have "the colour of the pickled pig parts," which is offset by German perceptions of her as "das Schwartze Mädchen" (12). Marija's offer of "pickled gherkins" and "cold cuts" after her icy embrace in her white bedroom with its "funeral elegance" causes Sissie to reason that "it had something to do with white skins, cornsilk hair and very cold weather" (68). This conception of whiteness, compounded with Nazism, and its inexorable association with inhumanity, which robs Marija of her warmth and sexual agency, stands in sharp contrast to the exotic appeal of snowy cold and the satin-like, silky desirability of the Swiss woman Zerelda's white breasts in Shoneyin's short story. Tellingly, both Our Sister Killjoy and "Woman in Her Season" deal with inter-racial lesbian relationships, as if the lesbian partner could only be a (Northern) European and never a consenting Nigerian (or African) woman.

In a 2005 contribution, Unoma Azuah has presented her own work as part of a Nigerian lesbian continuum, that comprises not only Shoneyin's short story but also Promise Okekwe's novel Women from the Crystal Deep (2002), in which Rebecca's lesbian leanings are stigmatized as being unnatural and evil desires, and Temilola Abioya's story "Taboo," in which Oyinkan daringly suggests in the midst of a conversation with four women: "Why don't we all take a shower and go down on each other. It wouldn't be copulating, it would be a lot of petting, smooching and caring." 8 In that same article, Azuah discusses her own story, "The Rebel," in which a woman suffers because of her sexual orientation and ultimately loses a lover to a monastery. She also examines her own poem "Onishe," which makes use of "the traditional symbols of eggs, blood, white yam, and cowries to convey the traditional picture of sacrifice and death" and in which she shows empathy with any "oppressed identity," "the lesbian" being only one facet of this larger configuration (137).

In order to give an all-round picture of Azuah, it is worthwhile to mention her poetry, which, as she admitted in her interview with Azuonye, is her "mistress," while "fiction is [her] wife." These other poems, which she does not discuss in her article, celebrate lesbian bonding. She is quite forthright in using words like "menstrual rags," "birth blood," and "wombs" as positive bodily means of empowerment for her fellow women. In "Queen of the Night," the title of which conventionally refers to a street prostitute, she celebrates a woman's love, as that woman, whom she has invited to "[c]reep into my cravings like snails / In their seasons ...," is seen further emerging "at full moon" to "fill [her] up like a yawn" (44), alluding to oral sex with her partner. In "Lekki Bitch," a poem around a beach in Lagos, Azuah comes up with a positive connotation for the word "bitch," in the same spirit of parody of Matthew Arnold's "Dover Beach" into "Dover Bitch," and she feminizes Lagos by presenting the infamous city as a woman dancing: "Her 
belly, damp, deep and dark / Her fullness, a dressed awe" (45), which can be read as pregnancy ${ }^{9}$ but which also suggests, I believe, clitoral arousal. In "Forbidden," Azuah voices the right to a lesbian relationship and refuses to seek refuge in the epistemic blindness to lesbianism proffered by compulsory heterosexuality: "My body is a bin / Where you dump your crumbs / To cast my ashes to the wind / Burn me in your gathered fire / I will not become a liar" (45). In "Nelo," she celebrates the callisthenics inherent in the passion of a woman lover: "Your beauty, like a wild panther, stalks / in the night of my soul / It scurries like a frightened squirrel / up the trees of my head/ It hurls winds of cravings with the/ rage of a hurricane" (14).

Upon their publication, these poems unleashed the male Nigerian critic Kalu Uduma's vengeful tirade against "the depravity, the instability and violence of our time" (17). More largely, those voices opposing African heteronormativity, which Juliana Abbenyi's Gender in African Women's Writing (1997) fails to address, clash not only with African patriarchy, but also with feminisms of African manufacture, such as the "misovirism" of the Cameroonian Werewere Liking; the "cultural feminism" or "feminism with a small $f$ " of the Nigerian Buchi Emecheta (31); spinoffs on womanism à la Alice Walker like what the Nigerian critic Chikwenye Okonjo Ogunyemi calls "Post-womanist discourse" (3-14); the Stiwanism of Molara Ogundipe-Leslie (203-41); or the "motherism" of Catherine Achonolu, which promotes motherhood as a source of empowerment for Nigerian women. The current matrifocal aspect of Nigerian domesticity may justify the heralding of maternity as the quintessence of Afrocentric femininitude but, as Azuah has remarked, "[I]t alienates not only women who cannot bear children but also women who choose not to be mothers" (130). Nigerian feminisms therefore need to make room for the material factors-what Jane Ussher has called "doing lesbian" to refer to lesbianism as "something that women do, rather than something they are" (150) - and the discursive factors that, in the Igbo or other African context, act together to define what it is to be lesbian. These feminisms also need to account for this budding literature, which (g)hosts same-sex desire.

In her debut novel, Sky-High Flames (2005), Azuah very timidly portrays desiring women. However, the reader, who is familiar with Azuah's poetry, with its clear lesbian overtones, is somewhat frustrated in her attempt to queer the novel, even though intimacy between women is very much present. The novel's epigraph from the well-known Igbo critic Emmanuel Obiechina-"the raw material of literature is the human experience which is put through the transforming 'sieve' of imagination" - serves as a cautionary tale to validate Azuah's claim that she is telling "a very small part" of her late Aunt 'Asua's story. That her aunt still "live[s] through [her]" as an ancestral spirit makes Azuah the ideal fictional conduit for this first-person narration, which, despite her sifting imagination, is firmly grounded in the Igbo sociological context, comprising a.o. ancestor worship, the cult of a female goddess, polygamy, and the levirate, which in turn encourages but also limits female agency within the post-independence patriarchal doxa.

Set in Igboland in the 1960s and 1970s, the novel chronicles the life of the young Igbo girl Ofunne, who overcomes "sky-high flames" or insurmountable obstacles before attaining self-realization. The sky-high fire seems to be fanned by men, as young Ofunne's nights are haunted by dreams of men as aggressors. In the first dream, she sees one man who "vomited into [her] mouth and laughed in 
[her] face" (20). In another dream, she "had wings, and [she] was climbing the hill to fly. [She] was halfway up, when a three-headed monster appeared beside [her], grabbed up [her] wings and clipped them" (42). This second dream is premonitory of Ofunne's doomed Icarus-like ascension, her waxen wings not only melting when nearing the sky-high flames but also precipitating her fall to Hades where Cerberus makes short shrift of her ambitions.

The first daughter of a polygamous household, Ofunne is burdened by domestic drudgery, yet ambitions "to be well-educated with a high-school certificate" (7). Her friend Awele, by contrast, is an only child, whose father resisted the sociocultural demands for polygamy and refused, unlike Ofunne's father, to take a second wife who would give him a son. From the outset, Ofunne takes a strong stance against polygamy, as she states. "There would be fewer problems if [her] father had only my mother as his wife" (25). Yet, Ofunne's father inherited Mama Isioma, his second wife, from his own father through the ancient law of the levirate. Mama Isioma is typically cast as a witch, not only on account of her dealings as a medicine woman successfully rivaling the male ritual specialists, or dibia, but also because she had two miscarriages, which were construed as infanticide in Medea-like fashion. Ofunne sanctions the biased indictment of women such as Mama Isioma while Azuah subtly points to the underlying patriarchal and Christian make-up, which demonized traditional healers and other powerful women, who controlled the subsistence economy. Christianity is, however, not conceived as entirely responsible for things falling apart since at the Enugu Teachers' Training College that Ofunne later joins, she reassesses her own culture through the Christian lens, and reflects that an old, bent nun would have been branded as "a witch" (64) in Igboland, whereas in the Christian school, the old hunchback is the object of much benevolence.

Very often, Ogunne goes against the patriarchal grain and queers the general distribution of sex roles. Such transgressions are often achieved through moments of intimacy with women, what Elleke Boehmer has called, when discussing Zimbabwean literature, implicit queerness as "a particular searching and interrogative approach to relations between women and to women's sexual identity" (117) ${ }^{10}$ One such scene involves Ofunne and her best childhood friend Awele going to the river Niger to display their swimming prowess to each other. The spectacle that the two girls have staged for each other, in which her friend swims "like a mermaid" (25), presumably with a sexuality still locked within her fish-like tail, is cut short by boys, who attempt to intimidate them. Ofunne comes to the rescue of her friend and "tickles" the boys (there is a euphemistic hint at Ofunne grabbing a boy's private parts), calling them diminutive "shrimps" (26). Even though Ofunne's bravura caused them to flee, patriarchy steps in, in the guise of Ofunne's younger brother, to take credit for the boys' demise, claiming, "If [he] had been around, [he] would not only have tickled their toes, [he] would've drowned them along with their toes" (27). A ten-year-old male emerges as a victor ludorum in this competition and gets the seal of approval by their father, who, Ofunne conjectures, would glorify her brother as having "a good sense of responsibility as a man. It was only right for a man to protect us ..." (27).

Another such moment of intimacy occurs at the Teachers' Training College, where Ofunne excels at defying the fixity of gender identity, as she is a feisty and rebellious tomboy, who gets into physical fights and often takes the law in 
her own hands. After initially thinking of the Reverend Sister Maureen Dolan as "an albino" who "speaks through the nose" (40), Ofunne overcomes her physical repugnance-cum-attraction for racial difference and succumbs to the Sister's dedication, strength, and modesty, as she did "what some of us students would not want to be caught doing, like cleaning out a pigsty" (65). After being attacked by an irate nursing pig, Ofunne sweetly surrenders to the Sister's caring hands, as she cleans her wounds on her legs and face: "As she cleaned my head, she held it close to her bosom-her dress smelt of scented wax" (63). This attraction could be likened to Jane Eyre's "admiring awe" (57) for Miss Temple, without involving what I have called elsewhere "the stuff of desire" (see Zabus, "Out of Africa"). But this intimacy culminates with Ofunne's enthused hugging of Sister Dolan who "hugged [her] back" (78) after the latter offered Ofunne an office job that would help her pay the school fees and bargain an extra year in school from Ofunne's prospective husband, Oko Okolo, to whom her father has hurriedly married her off for pecuniary reasons. Although Ofunne is eager to embrace the Sister's offer, she is nonetheless not averse to the principle of marriage, for she is aware that it "would be a curse not to be married and have children" (64). The reciprocity of that hugging from the school principal in such a regimented, hierarchical environment such as an all-girls" school is imbued with "the beauty and libidinality of transgression," as the South African exile Bloke Modisane eloquently put it in another context (299).

Nevertheless, what could be considered as "missing" in the novel, especially in the second part dealing with Ofunne's five-year-long training at an exclusive girls' school where girls sleep in communal dormitories and are expected to take baths in "an open wide bathroom" (39) is sexuality, as if desire had been excised from the narrative. The notion of "situational homosexuality," as notably defined by Robert Aldrich in his seminal Colonialism and Sexuality (2003), is of no help here since Aldrich is concerned only with (colonial) males and his overall argument on circumstantial homosexuality is controversial in that it evacuates queer desire, as in the "mine-marriages" between the indunas and their "boy-wives" in the South African all-male, mining complexes (3). ${ }^{11}$ Certainly, "situational homosexuality" in a West African context does not do justice to, for instance, the supis in the Ghanaian boarding school system, that is, the girl partners to whom girls have a strong attachment. In that regard, Nii Ajen contends that "supis participated in sexual activities in secrecy but until one party decided to release the information (because of a disagreement) not much would be known" (130). Yet, as A. Lambert has demonstrated in No Talking after Nights (1991), regarding boarding school girls, "occasionally a 'pash' between a pretty junior and a receptive senior might lead to a secret meeting in the long grass at the end of the games field. They would usually just talk, unfamiliar with the vocabulary of desire, hardly knowing why they wanted to be alone, until by accident they brushed against each other's little breasts and discovered how nice it felt" (99). Lambert's conclusion that most "pashes" were over before reaching even "this innocent stage" suggests that the schoolgirl "crush" is a necessary prelude to the "serious business" of adult heterosexuality. Yet, as Jane Ussher has gleaned from American girls' comic and teenage magazines (in Fantasies of Femininity, 1997) and from the host of girls' boardingschool stories (in Body Talk, 1997), lesbian interviewees have provided support for the notion of lesbianism "as a 'true' or pre-given sexual identity," that is, a 
"pre-given state, waiting to be discovered or expressed" (149). However, these tales of sexual self-discovery match those by girls who experienced the same feelings but never questioned their status as heterosexual. What is adumbrated in Azuah's narrative is the shifting of the various subject positions of being, doing, resisting or subverting "girl" but she has suppressed the boarding schoolgirls "doing lesbian," to use Ussher's phrase, ${ }^{12}$ and has thus failed to allow their sexuality to develop as a set of repeated performances in the sense in which Judith Butler famously introduced performativity - "[gender] identity is performatively constituted by the very 'expressions' that are said to be its results" (33).

The boarding school girls at the Teachers' Training College that Ofunne attends are, however, not completely unaware of the fluidity of shifting performance. Physical intimacy between young and older women is discursively confined to the flogging that teachers inflict upon students but without any mention of the psychic consequences of corporal punishment, let alone the girls' recuperation of flogging in sadomasochistic terms, such as those famously evoked by JeanJacques Rousseau in his Confessions, admittedly a quintessentially male text, when his spanking at the age of ten by Mlle Lambercier brings about his sexual arousal and the painful stimulation of the skin of the buttocks augurs masochism before the letter. ${ }^{13}$ Although Azuah does not tell us whether a whip or a stick is involved or whether the girls thus chastised have to remove their clothes or not, it remains that the girls' physical contact, via a punitive rod, with a figure of authority may have been a source of trauma and may have brought about the awareness of a violation of one's bodily integrity and therefore of a transgression. The confessional scenario by proxy (Azuah-Ofunne-'Asua) suggests an allegory of sexual self-discovery, which deviates into fiction, as indeed all sexuality does, since it inevitably rests on unconscious, infantile-determined scenarios of fulfillment.

At the school at Enugu, in a sexualized geography where the surrounding, feminized landscape is framed by "frightening" "sharp-edged hills," one of which looked like "a face with ears and eyes" with grasses blowing in the wind "like waving hairs [sic]" (41), desire is carefully evacuated, sanitized, and one wonders why the most vocal lesbian writer on the West African literary scene chose to tighten the lid over Pandora's box and allowed the potential amitiés particulières to be dulled by the college's monotonous routine of meals, siestas, bells, afternoon preps, and prayers. By contrast, a novel like Cracks (1999) by the South African Sheila Kohler goes to the opposite extreme in making the bisexual swimming teacher Miss G. the rapist of one of her wards.

If Azuah is rather diffident at providing the dangerous supplement ${ }^{14}$ to her aunt 'Azua's story, she is quite comfortable dwelling on the physicality of heterosexual relationships, as in the third and fourth parts of the novel, devoted to Ofunne's married life with Oko Okolo, who, far from being the revolutionary "voice" (okolo in Ijo) of Gabriel Okara's famed novel The Voice, is a caricature of conventional masculinity. He is "handsome, tall, and dark" (80), and upon visiting Ofunne for the first time at the school, he unabashedly ogles her friend's breasts. Azuah devotes quite a bit of narrative space to Oko's first overtures, as she focuses, without any trace of embarrassment, on his groin, "hard on [her] buttocks" and Ofunne yelping in horror at the "sight of his long and stiff penis ... swinging back and forth as if it had a life of its own" (95). After Ofunne is married in church with no further ado, on their wedding night, Oko "jabbed at [her] with such hostility that [she] told 
him to slow down and he tried, but every jab came with such an intense pain that [she] pushed him off several times" (95) and was unable to walk for several days. Despite the harrowing severity of this forcible defloration, Azuah manages to fill the interstices of pain with humor. Male sexual exertions are often ridiculed, as Oko is described as "moaning and panting like a tired sprinter, till he convulsed like an epileptic patient" (138).

It turns out that Oko has few redemptive features, as he is a fraud, who lied about his job, his faith, and his morals. As soon as she settles in Oko's room in Zabo, the populous northern city of Kaduna's largest districts, Ofunne is confronted with the evidence-a pink dress-that her husband has lady friends and her suspicions are confirmed later when a prostitute walks into their humble abode, with shifting wig and smudged make-up. Oko's connection with the sordid world of prostitution would be benign, especially in light of some general tacit understanding that "men are like that-polygamous" (100), if it did not bring about syphilis. The specter of sexually transmitted diseases lingers over the last part of the novel, which reflects the pandemic of AIDS in West Africa and elsewhere but also, more locally, the belief that some Nigerian males cherished, according to which sleeping with a virgin would rid them of the virus once and for all. Ofunne learns through reading his diary that Oko had contracted syphilis several years ago and, later, when faced with a doctor, rather than the preferred midwife, she finds out that syphilis has reached such an advanced state that her baby is stillborn. Heterosexuality is here presented as synonymous with contamination and death.

If homosexuality is only parsimoniously hinted at in Queen Elizabeth's dormitory, where Ofunne and Awele spend five years in close proximity, sexuality in its heterosexual form is carefully controlled. Sister Dolan is especially apt at quenching any desire for the opposite sex, since she repeatedly warns the girls against "the different types of sexual diseases [they] could contract, if [they] had sex before marriage" (66). The girls feel it incumbent to "monitor [them]selves" by instituting a form of ostracism: "[W] hoever received a love letter that [they] found out about was booed at and to an extent ostracized, because they would be known as bad girls" (66). The "bad girls" syndrome finds its corollary in the "Pure Girls" perplex, which has been injected into the girls through the story of Saint Maria Goretti, who "had chosen to die rather than be defiled by being raped" (66). In her fervor, Awele has won many converts. Her "mission" to convert her peers to the Goretti cult of sexual purity is very much akin to Helen Burns's mystical and ascetic self-erasure, which acts as a foil to Jane Eyre's more fleshly appetites. However, in the newly Christianized girls' psyche, Goretti grades into the Virgin Mary and Onishe, the river goddess.

Set at a one-century remove from Chinua Achebe's famous recording of the falling apart of things Igbo following the arrival of the white man, the novel also takes pains to present the encroachment of Christianity on the Igbo ancestral belief system. Just as the worship of the goddess Idemili was superior to the cult of the ancestors, thereby suggesting, as Amadiume does, an Nnobi matriarchal settlement, later encroached by patriarchal Nri people (42), the worship of Onishe, in its postcolonial variant, is, if no longer superior, adjacent to the cult of (male) ancestors.

Rather than casting, as Achebe did, an Egwugwu, or masquerader, who had "the springly walk of Okonkwo," a fact dimly envisaged by his wives and women 
bystanders, who stand outside of the purview of male knowledge about the clan's most secret cult (63-64), Azuah makes Ofunne's father a well-known, visible member of the masquerade cult who, on one occasion in the novel, is reported to have "gone with other elders of the village to convey the masked spirits of our ancestors down to the river Niger" (2). He is also a fervent worshipper of the river goddess Onishe, who, throughout the narrative, is associated with a female-oriented and matrifocal ancestral worldview. As the guardian of Ofunne, Onishe soon finds a rival in the male, monotheistic, Christian deity, that Reverend Sister Dolan introduces to the at first incredulous girls.

Ofunne and Awele are exposed to the "fat black book," that is, the Bible, and to estranging gestures such as signing oneself, along with the metal "fighting tools" that are the knife, the spoon, and the fork, which the bemused girls have to use with the left hand, against Igbo propriety. As Ofunne is glumly told that "[her] father's laws end here" (47), she is swiftly made to submit to the nun's laws. One day in class, Ofunne is asked to provide a definition of God and when Ofunne confidently answers that he is "almighty, the Creator of heaven and earth" (54), which meets her teacher's enthusiastic approval, what she has in mind is Chukwu (although Azuah does not say so), the Igbo god, who, in polytheistic fashion, comes "along with other gods and goddesses like Onitshe [sic]-goddesses of the water. Ani, goddess of the earth, Akpala, god of thunder and lightening" (54). Although Ofunne aims to abide by her father's parting advice and remain loyal to Onishe, she catches herself invoking "the Christian God worshiped in [her] school church" (56). As Ofunne is slowly but surely converted to Catholicism, the Catholic sense of guilt creeps in. She protests that she "never denounced Onishe, but saw her as Mary the mother of God, though Onishe was not pale-looking, and even though she had long dreadlocked hair" (64). Her beating the girl with "her marked face"-a face with "two incision marks on both cheeks" (56) follows directly upon her invoking the Christian God, recalling the Christian missionaries' early demonization of facial markings during the colonial period, as if Ofunne had internalized colonial Christianity's most rigid tenets. Ofunne also later scorns her husband's mother, who claims to be a "good Catholic," yet spends time in the forest looking for "potent herbs to prepare curses for her vengeful clients" (145). But even before the proselytizing nuns got hold of Ofunne's soul, she had already castigated Mama Isioma's attempt at placing a curse over her mother's head in "a plot of death" (21) as contrary to Christian belief, which shows Azuah's authorial denunciation of the "animistic" belief system. As Azuah confessed in the Azuonye interview, "the Catholic in [her]" is fond of looking at "the futility of unbelief and faith."

The novel concludes with Ofunne's visit to Onishe's shrine where she prays to be cured of her illness and to go back to school. This finale echoes, to some extent, Flora Nwapa's Efuru (1966), which concludes with the eponymous Efuru embracing as ultimate figure of motherhood Uhamiri, the goddess or woman of the lake, as the one who "truly responds to Efuru's innermost needs and wishes" (98) and, in addition, giving the lie to Chinua Achebe who, in Things Fall Apart, had genderized the Goddess as "the God of water" (112). With Ofunne's return to Onishe, SkyHigh Flames also ends with the tightening of bonds between mother and daughter, which was at first fraught with tensions. In the process, Azuah allows this story of women to be crowned by a renewed reverence for the feminine. 
Contrary to anthropological solicitations such as John McCall's interview with Nne Uko, an elderly Ohafia Igbo female husband who, in 1996, claimed she never "took her wives to bed" (130), the Nigerian novel has the capacity to comment on the economy of pleasures and on the way of constituting oneself as the moral subject of one's sexual conduct. Admittedly, such a novel is still in the making but writers like Unoma Azuah (and Promise Okekwe) are showing the way. Interestingly, in representing homosexuality and gender bending, Nigerian and, more particularly, Igbo women have been more vocal than their male counterparts, possibly because of Igbo women's powerful matriarchal past, their historically documented capacity for mobilizing, as in the 1929 Aba riots against the colonial powers, and a womanly relationality such as Azuah's displaced (auto)biographical vestment in her aunt's story. The author of Sky-High Flames is, as the Igbo ilù goes, ${ }_{1}^{15}$ the fire-bearer who must perforce be haunted by the trail of smoke.

\section{NOTES}

1. The first, pioneering study of homosexuality in African fiction is a 1989 article by Chris Dunton, which appeared in Research in African Literatures. Taking his cue from Daniel Vignal's 1983 incursion, Dunton examines Yulissa Amadu Maddy's No Past, No Present, No Future (1973); Ama Ata Aidoo's Our Sister Killjoy (1977); Wole Soyinka's The Interpreters (1972); and Yambo Ouologuem's Bound to Violence (1971).

2. Reincarnation, in the context described by Leith-Ross, entails that a male or a female ancestor enters the child at birth and is named accordingly by the dibia.

3. Warm thanks go to Françoise Ugochukwu for pointing this out to me as well as Amadiume's Igbo misspellings. Whereas oke means male, anyi does not connote the feminine but is rather akin to "our."

4. With reference to the work of Amadiume and of Murray and Roscoe, Neville Hoad has made some striking critical observations on "the uses to which ethnographic and anthropological approaches to the question of 'homosexuality' and 'Africa' have been put" (19-23).

5. Huntingford, p. 412, qtd. in Carrier and Murray, "Woman-Woman Marriage in Africa" 27. The absence of sexual intercourse was confirmed by Oboler $(1985,1980)$.

6. For a rebuttal to Herskovits, see Krige and Obbo. Obbo writes: "[W]e cannot know whether Dahomean women who practiced woman-to-woman marriage were lesbians or whether it was a slip of Herskovits' pen." And later: "While no one can categorically dismiss the possibility that a woman-to-woman marriage may involve a homosexual relationship, there is no excuse for assuming it" $(385, \mathrm{n} 4)$. Carrier and Murray comment: "[Obbo] does not explain, however, what might be 'heterosexual' in female-female mutual masturbation, a practice that does not seem to involve gendered roles" (264).

7. Susan Arndt uncritically endorses Aidoo's sarcastic assimilation of Sissie with the Third Reich and Nazism (163-65).

8. Promise Okekwe, "Rebecca," unpublished 1997 ms., now part of the novel, Women from the Crystal Deep (Lagos: Oracle, 2002); and Temilola Abioye, "The Taboo," unpublished ms. Qtd Azuah, "The Emerging Lesbian Voice ...," p. 134 \& p. 136.

9. Many thanks go to my Ph.D. student, Chika Unigwe, for introducing me to Azuah's lesser known poetry. See her dissertation, pp. 89-90, where she evokes pregnancy. I look at some of these poems in the larger African context in Zabus, "The Text."

10. In her treatment of Zimbabwe's two most prominent women writers, however, Tsitsi Dangarembga and Yvonne Vera, I consider that such an "approach" has to be backed 
up by (sexual) desire, what I call the stuff of desire, and that, if this ingredient is lacking, it signals the limits of queering African novels in the sense Boehmer suggests.

11. See also Moodie. For a critique of Moodie, see Achmat; McLean and Ngcobo; and Spurlin.

12. Incidentally, Ussher fails to mention bisexuality.

13. Rousseau - "[J]'avais trouvé dans la douleur, dans la honte même, un mélange de sensualité qui m'avait laissé plus de désir que de craintes de l'éprouver derechef par la même main."

14. Originally from Rousseau"J'appris ce dangereux supplément qui trompe la nature" (109) to refer to masturbation.

15. This Igbo proverb, or ilù-"the fire bearer must be haunted by the trail of smoke" -is spoken by Ofunne's mother after the co-wife Mama Isioma's "plot of death." Incidentally, this is followed by a chi saying - "If I am guilty, I will pay. If I am not, my chi is never asleep" (22)—in the best Achebe tradition.

\section{WORKS CITED}

Achebe, Chinua. Things Fall Apart. 1958. London: Heinemann, 1986.

Achmat, Zackie. "'Apostles of a Civilised Vice': 'Immoral Practices' and 'Unnatural Vice' in South African Prisons and Compounds, 1980-1990.'" Social Dynamics 19.2 (1993): 92-110.

Achonulu, Catherine. "Motherism: The Afrocentric Alternative." Ishamel Reed's Konch Magazine" Mar.-Apr.2002: n.p.

Aidoo, Ama Ata.Our Sister Killjoy. New York: Longman, 1977.

Ajen, Nii. "West African Homoeroticism: West African Men Who have Sex with Men." Murray and Roscoe 128-38.

Aldrich, Robert. Colonialism and Homosexuality. London: Routledge, 2003.

Amadiume, Ifi. Male Daughters, Female Husbands: Gender and Sex in an African Society. London: Zed, 1987.

Arndt, Susan. "Boundless Whiteness? Feminism and White Women in the Mirror of African Feminist Writing." Body, Gender, Sexuality 157-72.

Azuah, Nuoma Nguewmo. Night Songs. Lagos: Oracle, 2000.

. Sky-High Flames. Baltimore: PublishAmerica, 2005.

. "The Emerging Lesbian Voice in Nigerian Feminist Literature." Body, Sexuality, and Gender 129-41.

Azuonye, Nnorom. "Interview with Unoma Azuah." Sentinel Poetry Quarterly 4 (2005). available on http://nnorom.blogspot.com/2006/07/interview-with-unoma-azuah. html (last accessed Oct. 13, 2006).

Boehmer, Elleke. "Versions of Yearning and Dissent: The Troping of Desire in Yvonne Vera and Tsitsi Dangarembga." Body, Sexuality, Gender 113-28.

Butler, Judith. Gender Trouble: Feminism and the Subversion of Identity. New York: Routledge, 1999.

Brontë, Charlotte. Jane Eyre. 1847. London; Penguin, 1996.

Carrier, Joseph M., and Stephen O. Murray. "Woman-Woman Marriage in Africa." Murray and Roscoe 254-66.

Dunton, Chris. "'Wheyting be Dat?' The Treatment of Homosexuality in African Literature." Research in African Literatures 20.3 (1989): 422-45.

Emecheta, Buchi. "Tributes." Emerging Perspectives on Flora Nwapa. Ed. Marie Umeh. Trenton, NJ: Africa World P, 1998. 
Evans-Pritchard, Edward E. Kinship and Marriage among the Nuer. Oxford: OUP, 1951.

Fielding, Henry. "The Female Husband." The Literature of Lesbianism: A Historical Anthology from Ariosto to Stonewall. Ed. Terry Castle. New York: Columbia UP, 2003. 272-87.

Gaudio, Rudolph. "Male Lesbians and Other Queer Notions in Hausa." Murray and Roscoe 115-28.

Gay, Judith. "'Mummies and Babies' and Friends and Lovers in Lesotho." Journal of Homosexuality 11.3-4 (1985): 97-116.

Herskovits, Melville J. "A Note on 'Woman Marriage' in Dahomey." Africa 10 (1937): $335-41$.

Hoad, Neville. African Intimacies: Race, Homosexuality and Globalization. Minneapolis: $\mathrm{U}$ of Minnesota P, 2006.

Huntingford, George W. B. "Nandi of Western Kenya." Cultural Source Materials for Population Planning in East Africa: Beliefs and Practice.Ed. Angela Molnos. Nairobi: East African Publishing House, 1973. 406-14.

Kendall, [Kathryn]. “'When a Woman Loves a Woman' in Lesotho: Love, Sex, and the (Western) Construction of Homophobia." Murray and Roscoe 223-41.

Kohler, Sheila. Cracks. 1999. London: Bloomsbury, 2002.

Krige, Eillen Jensen. "Woman-Marriage, with Special Reference to the Lovedu." Africa 44 (1974): 11-36.

Lambert, A. No Talking After Nights. London: Penguin, 1991.

Leith-Ross, Sylvia. African Women, a Study of the Ibo of Nigeria. With a Foreword by Lord Lugard. London: Faber and Faber, 1939.

McCall, John C. "Portrait of a Brave Woman." American Anthropologist 98 (1996): 127-36.

McLean, Hugh, and Linda Ngcobo. "Abangibhamaya bathi ngimmandi (Those Who $\mathrm{F}^{* * \star}$ Me Say I'm Tasty): Gay Sexuality in Reef Townships." Defiant Desire: Gay and Lesbian Lives in South Africa. Ed. Mark Gevisser and Edwin Cameron. New York: Routledge, 1995. 158-85.

Mead, Margaret. Male and Female. 1949. With an Introduction by Helen Fisher. New York: Harper Collins/Perennial, 2001.

Modisane, Bloke. Blame Me on History. 1963. New York: Simon and Shuster, 1990.

Moodie, T. Dunbar, et al. "Migrancy and Male Sexuality on the South African Gold Mines." The Journal of African Studies 14.2 (1988). Rpt in Martin Duberman, Martha Vicinus, and George Chauncey, Jr., eds. Hidden from History: Reclaiming the Gay and Lesbian Past. New York: Merdian, 1989. 411-25.

Murray, Stephen O., and Will Roscoe, eds. Boy-Wives and Female Husbands: Studies in African Homosexualities. New York: Palgrave/St Martin's Griffin, 1998.

Nwapa, Flora. Efuru. London: Heinemann, 1966.

Obbo, Christine."Dominant Male Ideology and Female Options: Three African Studies." Africa 46 (1976): 371-89.

Oboler, Regenia Smith. “Is the Female Husband a Man?" Ethnology 19 (1980): 69-88.

Oboler, Regenia Smith. Women, Power, and Economic Change. The Nandi of Kenya. Stanford: Stanford UP, 1985.

O'Brien, Denise. "Female Husbands in Southern Bantu Societies." Sexual Stratification: A Cross-Cultural View. Ed. Alice Schlegel. New York: Columbia UP, 1977. 109-26.

Ogundipe-Leslie, Molara. "Stiwanism: Feminism in an African Context." Re-Creating Ourselves, African Women and Critical Transformations. Ed. Molara Ogundipe-Leslie. Trenton, NJ: Africa World P, 1994. 207-41. 
Ogunyemi, Okonjo Chikwenye. "Tête-à-tête with the Chief: Post-Womanist Discourse in Bessie Head's Maru." Body, Sexuality, and Gender 3-14.

Rousseau, Jean-Jacques. Les confessions. Paris: Editions Baudelaire, 1966.

Shoneyin, Lola. “Woman in Her Season." Post Express Jan. 25, 1997: 12.

Spurlin, William J. “Broadening Postcolonial Studies/Decolonizing Queer Studies: Emerging 'Queer' Identities and Cultures in Southern Africa." Postcolonial, Queer: Theoretical Intersections . Ed. John C. Hawley. Albany: State U of New York P, 2001. 185-205.

Taiwo, Oladele. Female Novelists of Modern Africa. London: Macmillan, 1984.

Uduma, Kalu. "The Lesbian Voice in Current Nigerian Literature." Sunday Vanguard Feb. 23, Art page: 17.

Unigwe, Chika. "In the Shadow of Ala: Igbo Women's Writing as an Act of Righting." Diss. U of Leyden, 2004.

Ussher, Jane M. Fantasies of Femininity: Reframing the Boundaries of Sex. London: Penguin, 1997.

Ussher, Jane M., ed. Body Talk: The Material and Discursive Regulation of Sexuality, Madness and Reproduction. London: Routledge, 1997.

Vignal, Daniel. "L'homophilie dans le roman négro-africain d'expression anglaise et française." Peuples noirs, peuples africains 33 (May-June 1983): 63-81.

Zabus, Chantal. "The Text That Dare Not Speak Its Name: Contextual Heterosex and Same-Sex Desire in African Fiction." Commonwealth: Essays and Studies 28.1 (2005): $10-24$.

. "Out in Africa." Comparative Cultural Studies. Spec. issue. Ed. Margaret Higonnet. U of Edinburgh P, forthcoming 2008. 